Review Article

\title{
Oxidative Stress Links Aging-Associated Cardiovascular Diseases and Prostatic Diseases
}

\author{
Ming-Juan Zhao $\mathbb{D}^{1},{ }^{1}$ Shuai Yuan $\left(\mathbb{D},{ }^{1}\right.$ Hao Zi $\mathbb{D}^{1,2}$ Jia-Min Gu $\mathbb{D}^{1,2}$ Cheng Fang $\mathbb{D}^{1}$, \\ and Xian-Tao Zeng (iD ${ }^{1,2}$ \\ ${ }^{1}$ Center for Evidence-Based and Translational Medicine, Zhongnan Hospital of Wuhan University, Hubei, Wuhan 430071, China \\ ${ }^{2}$ Department of Urology, Zhongnan Hospital of Wuhan University, Hubei, Wuhan 430071, China
}

Correspondence should be addressed to Cheng Fang; vitsippa@whu.edu.cn and Xian-Tao Zeng; zengxiantao1128@whu.edu.cn

Received 12 May 2021; Revised 17 June 2021; Accepted 3 July 2021; Published 19 July 2021

Academic Editor: Yue Liu

Copyright (c) 2021 Ming-Juan Zhao et al. This is an open access article distributed under the Creative Commons Attribution License, which permits unrestricted use, distribution, and reproduction in any medium, provided the original work is properly cited.

\begin{abstract}
The incidence of chronic aging-associated diseases, especially cardiovascular and prostatic diseases, is increasing with the aging of society. Evidence indicates that cardiovascular diseases usually coexist with prostatic diseases or increase its risk, while the pathological mechanisms of these diseases are unknown. Oxidative stress plays an important role in the development of both cardiovascular and prostatic diseases. The levels of oxidative stress biomarkers are higher in patients with cardiovascular diseases, and these also contribute to the development of prostatic diseases, suggesting cardiovascular diseases may increase the risk of prostatic diseases via oxidative stress. This review summarizes the role of oxidative stress in cardiovascular and prostatic diseases and also focuses on the main shared pathways underlying these diseases, in order to provide potential prevention and treatment targets.
\end{abstract}

\section{Introduction}

Cardiovascular diseases (CVDs), including hypertension, coronary heart disease (CHD), cerebrovascular disease, and heart failure, are the major cause of death globally. In the period from 1990 to 2019, the prevalence of total CVD nearly doubled from 271 million to 523 million cases, and the number of CVD deaths steadily increased from 12.1 million to 18.6 million [1]. In 2019 , ischaemic heart disease was one of the top-ranked causes of disability adjusted life years (DALYs) in both the 50-74-year and 75-years-and-older age groups [2]. According to World Health Organization (WHO) statistics, almost 23.6 million people will die from CVDs by 2030. Benign prostatic hyperplasia (BPH) and prostate cancer are also aging-associated diseases. The incidence rate of BPH increases with age affecting about $50 \%$ of men over 50 years, increasing to $80 \%$ when they reach 80 or above $[3,4]$. There is also an increased incidence in prostate cancer cases from 940,000 in 2007 to 1.3 million in 2017 [5], and the age-standardized incidence of prostate cancer in China also rose by $2.75 \%$ from 1990 to 2017 [6]. Aging clearly plays an important role in CVDs (such as hypertension and $\mathrm{CHD}$ ) and prostatic diseases (prostate cancer and $\mathrm{BPH}$ ).

The current evidence suggests that CVDs usually coexist with prostatic diseases or increase its risk, and there are 13 related clinical studies showing CVD as a risk factor for prostatic diseases (see Table 1); however, whether there is a causal relationship between them is still controversial. Numerous studies have reported that oxidative stress can promote the occurrence and development of both prostatic diseases and CVDs [7-10]; hence, to summarize its role in these two diseases can provide information for seeking prevention and potential therapeutic targets.

\section{Oxidative Stress}

The concept of oxidative stress originated from human understanding of aging. In 1956, Professor Harman first proposed the theory of free radical aging. In 1990, Professor Sohal pointed out the flaws of this theory and put forward the concept of oxidative stress for the first time [24, 25]. 


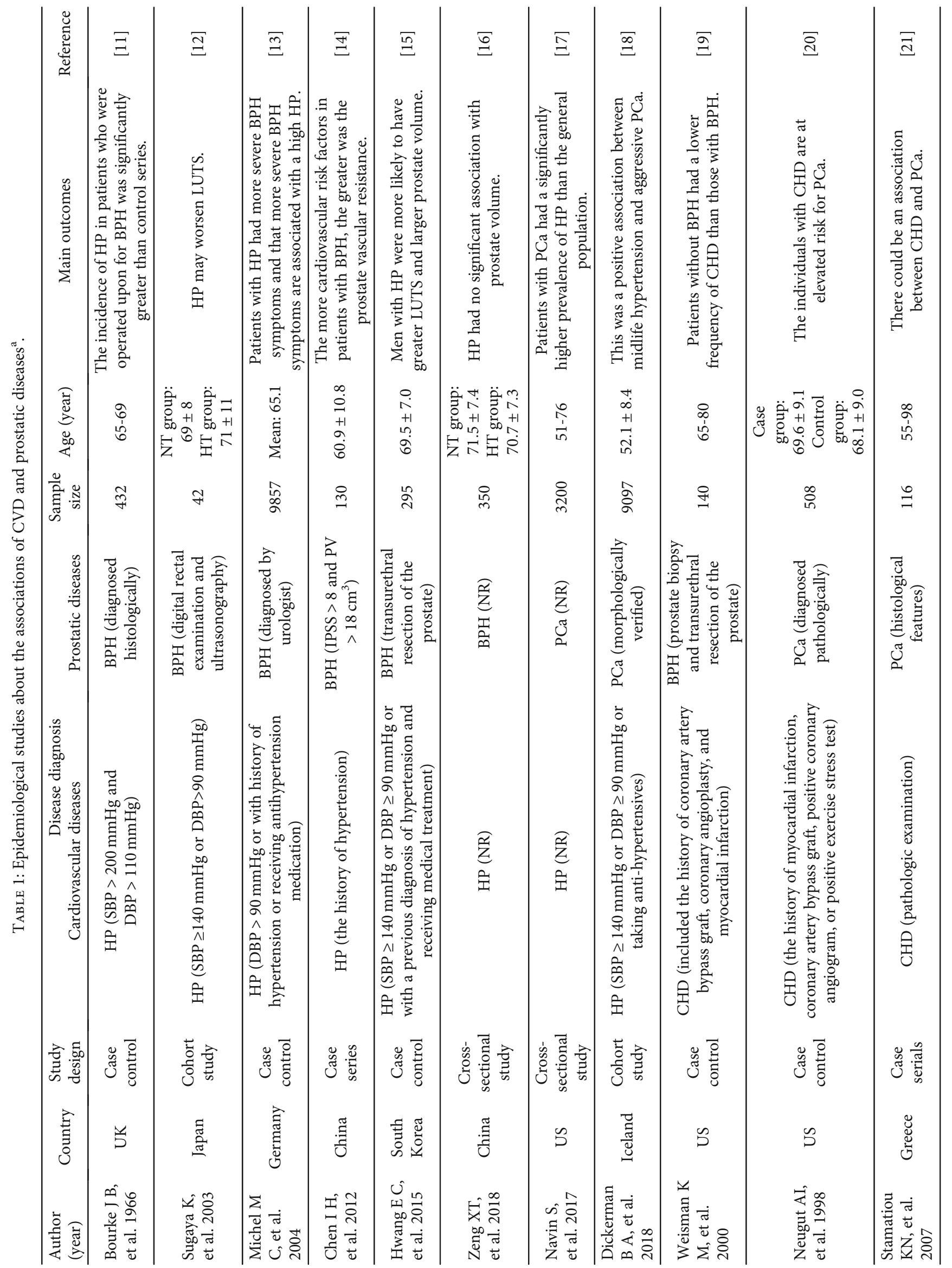




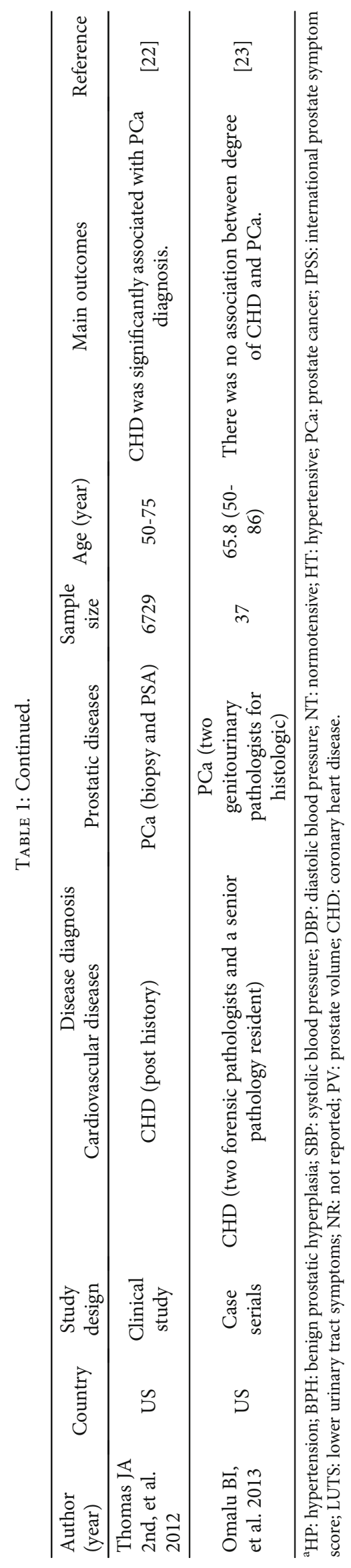




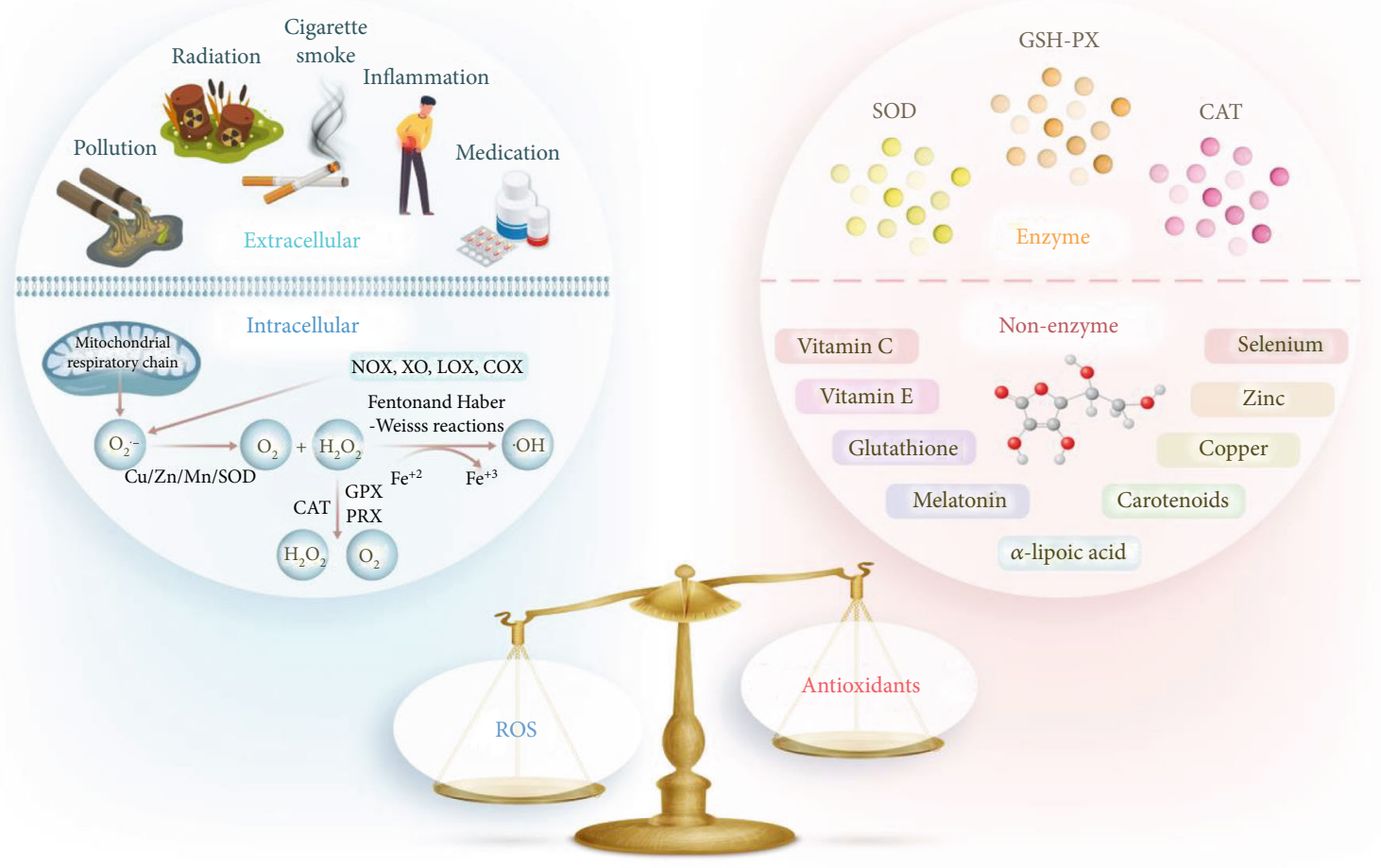

FIGURE 1: Schematic representation of the oxidative stress theory and the sources of ROS and antioxidants. When the generation of ROS outweighs antioxidative capacity, this leads to oxidative stress. ROS are generated from extracellular and intracellular sources. The extracellular sources of ROS are pollution, inflammation, cigarette smoke, radiation, and medication. Intracellular sources of ROS are the mitochondrial electrotransport chain: NADPH oxidase (NOX), xanthine oxidase (XO), lipoxygenase (LOX), and cyclooxygenase (COX). The enzyme antioxidant system includes superoxide dismutase (SOD), catalase (CAT), glutathione peroxidase (GSH-PX), and the nonenzyme antioxidant system includes vitamin $\mathrm{C}$, vitamin $\mathrm{E}$, glutathione, melatonin, $\alpha$-lipoic acid, carotenoids, and trace elements such as copper, zinc, and selenium.

Oxidative stress is a situation where the balance of oxidative systems and antioxidative systems in vivo is changed in favour of the former $[26,27]$. Oxidants are regulators of normal cellular function, but when the production of reactive oxygen species (ROS) exceeds the scavenging capacity, the oxidation and antioxidant systems will be unbalanced, causing damage to the tissues and cells; this phenomenon is called oxidative damage [28-30]. ROS includes superoxide anion $\left(\mathrm{O} 2^{\bullet-}\right)$, hydroxyl radical $(\bullet \mathrm{OH})$, and hydrogen peroxide $\left(\mathrm{H}_{2} \mathrm{O}_{2}\right)$. To maintain the balance, there are two antioxidative systems in vivo: one is the enzyme antioxidant system, including superoxide dismutase (SOD), catalase (CAT), and glutathione peroxidase (GSH-PX), and the other is the nonenzyme antioxidant system which includes vitamin $C$, vitamin E, glutathione, melatonin, $\alpha$-lipoic acid, carotenoids, and trace elements such as copper, zinc, and selenium (SE). Figure 1 presents the oxidative stress theory and the sources of ROS and antioxidants.

2.1. Characteristics of ROS. ROS are generated by a variety of extracellular and intracellular actions (Figure 1). The main intracellular source of ROS is the mitochondrial respiratory chain. The $\mathrm{O} 2^{\bullet-}$ is the principal ROS formation which is produced by the enzymatic reaction and a nonenzymatic electron transfer reaction in cell. The enzymes that generate the superoxide include NADPH oxidase (NOX), xanthine oxidase (XO), lipoxygenase (LOX), and cyclooxygenase (COX) [31]. $\mathrm{H}_{2} \mathrm{O}_{2}$ is produced from $\mathrm{O} 2^{\bullet-}$ by enzymatic dismutation by the three isoforms of $\mathrm{Cu} / \mathrm{Zn} / \mathrm{Mn} \mathrm{SOD}$ in intracellular. Most of the $\mathrm{H}_{2} \mathrm{O}_{2}$ is converted to $\mathrm{H}_{2} \mathrm{O}$ by the catalase (CAT), glutathione peroxidase (GPX), and peroxiredoxins (PRX). $\mathrm{H}_{2} \mathrm{O}_{2}$ can damage DNA when it is converted to $\bullet \cdot \mathrm{OH}$ through Fenton and Haber-Weiss reactions in the transition metal ions, especially iron ions $\left(\mathrm{Fe}^{+2}\right)$. The $\bullet \mathrm{OH}$ is the most toxic form of ROS which causes various types of DNA damage, lipid peroxidation, and protein modification [32]. The extracellular sources of ROS commonly included pollution, inflammation, cigarette smoke, radiation, and medication [33].

At present, accurately measuring ROS in disease is still a problem. ROS are unstable, and their half-lives are relatively short. For example, the half-life of $\mathrm{O} 2^{\bullet-}$ is $10^{-6}$ to $10^{-9}$ seconds, and the $\bullet \mathrm{OH}$ is $10^{-9}$ seconds $[34,35]$. Therefore, ROS are routinely measured by biomarkers of oxidative damage, which included markers of protein damage (protein carbonyl derivatives), lipid peroxidation (malondialdehyde [MDA] and 4- 
TABLE 2: The summary of oxidative stress in CVD or prostatic diseases.

\begin{tabular}{|c|c|c|c|c|c|c|}
\hline Author (year) & $\begin{array}{l}\text { Study } \\
\text { design }\end{array}$ & $\begin{array}{c}\text { Study } \\
\text { population }\end{array}$ & Age (year) & Markers assessed & Main results & Reference \\
\hline $\begin{array}{l}\text { Germanò G, } \\
\text { et al. } 2004\end{array}$ & $\begin{array}{l}\text { Cross- } \\
\text { sectional } \\
\text { study }\end{array}$ & $\begin{array}{l}40 \text { persons } \\
\text { with HP } \\
40 \text { healthy } \\
\text { individuals }\end{array}$ & $\begin{array}{l}\text { HP group: } \\
51.6 \pm 3 \\
\text { Healthy } \\
\text { group: } 54.4 \\
\pm 2\end{array}$ & $\begin{array}{l}\text { (i) } \mathrm{O}_{2}^{-} \text {measured by } \\
\text { lucigenin } \\
\text { chemiluminescence } \\
\text { and hydroethidine } \\
\text { cytofluorimetric }\end{array}$ & $\begin{array}{l}\text { Patients with hypertension showed an } \\
\text { enhanced formation of } \mathrm{O}_{2}^{-} \text {in platelets. }\end{array}$ & {$[37]$} \\
\hline $\begin{array}{l}\text { Guxens M, } \\
\text { et al. } 2009\end{array}$ & $\begin{array}{l}\text { Cross- } \\
\text { sectional } \\
\text { study }\end{array}$ & $\begin{array}{l}819 \mathrm{CHD} \\
\text { patients with } \\
\text { HP } \\
311 \mathrm{CHD} \\
\text { patients } \\
\text { without HP }\end{array}$ & $\begin{array}{l}\text { HP group: } \\
67 \pm 8 \\
\text { Control } \\
\text { group: } 66 \pm 9\end{array}$ & $\begin{array}{l}\text { (i) Circulating ox-LDL } \\
\text { measured by an } \\
\text { enzyme-linked } \\
\text { immunosorbent }\end{array}$ & $\begin{array}{l}\text { There was a positive relationship between } \\
\text { circulating ox-LDL and hypertension. }\end{array}$ & {$[38]$} \\
\hline $\begin{array}{l}\text { Pinzón-Díaz } \\
\text { CE, et al. } \\
2018\end{array}$ & $\begin{array}{l}\text { Clinical } \\
\text { trial } \\
\text { study }\end{array}$ & $\begin{array}{l}12 \text { persons } \\
\text { with HP } \\
15 \text { healthy } \\
\text { individuals }\end{array}$ & $26-50$ & $\begin{array}{l}\text { (i) MDA by a } \\
\text { spectrophotometer } \\
\text { (ii) GSH concentration } \\
\text { used the glutathione } \\
\text { assay kit }\end{array}$ & $\begin{array}{c}\text { Compared to healthy patients, the level of } \\
\text { lipid peroxidation is higher } 2.1 \text { times in } \\
\text { hypertensive patients. }\end{array}$ & {$[39]$} \\
\hline $\begin{array}{l}\text { Zhao H, et al. } \\
2018\end{array}$ & $\begin{array}{l}\text { Clinical } \\
\text { trial } \\
\text { study }\end{array}$ & $\begin{array}{l}75 \text { people } \\
\text { with HP } \\
75 \text { healthy } \\
\text { people }\end{array}$ & $\begin{array}{l}\text { HP group: } \\
40.41 \pm 11.66 \\
\text { Control } \\
\text { group: } 40.08 \\
\pm 4.31\end{array}$ & $\begin{array}{l}\text { (i) Melatonin measured } \\
\text { by metabolomic }\end{array}$ & $\begin{array}{l}\text { Oxidative stress would cause disturbance } \\
\text { in hypertensive patients and affect the } \\
\text { metabolic pathway of pathogenesis. }\end{array}$ & {$[40]$} \\
\hline $\begin{array}{l}\text { Merendino } \\
\text { RA, et al. } \\
2003\end{array}$ & $\begin{array}{l}\text { Clinical } \\
\text { study }\end{array}$ & $\begin{array}{l}22 \text { patients } \\
\text { with BPH } \\
22 \text { healthy } \\
\text { subjects }\end{array}$ & $\begin{array}{l}\text { BPH group: } \\
65.8 \text { (56-79) } \\
\text { Control } \\
\text { group: } 62.1 \\
\quad(55-76)\end{array}$ & $\begin{array}{l}\text { (i) MDA measured a } \\
\text { commercially kit }\end{array}$ & $\begin{array}{l}\text { The results showed a higher level of MDA } \\
\text { in BPH patients. }\end{array}$ & {$[44]$} \\
\hline $\begin{array}{l}\text { Camphausen } \\
\text { K, et al. } 2004\end{array}$ & $\begin{array}{l}\text { Cohort } \\
\text { study }\end{array}$ & $\begin{array}{c}38 \\
\text { radiotherapy } \\
\text { PCa cases } \\
15 \text { received } \\
\text { placebo } \\
\end{array}$ & NR & $\begin{array}{l}\text { (i) Urinary 8-iso- } \\
\text { prostaglandin PGF } \text { PG }_{2 \alpha} \\
\text { and 15-keto-dihydro- } \\
\text { PGF }_{2 \alpha}\end{array}$ & $\begin{array}{l}\text { The study showed that there was no } \\
\text { statistically increase in } 8 \text {-iso- } \mathrm{PGF}_{2 \alpha} \text { or } 15- \\
\text { keto-dihydro-PGF } \\
\text { compared with normal control group. }\end{array}$ & {$[45]$} \\
\hline $\begin{array}{l}\text { Yilmaz MI, } \\
\text { et al. } 2004\end{array}$ & $\begin{array}{l}\text { Case- } \\
\text { control } \\
\text { study }\end{array}$ & $\begin{array}{l}50 \text { patients } \\
\text { with } \mathrm{BPH} \\
21 \text { patients } \\
\text { with } \mathrm{PCa} \\
50 \text { healthy } \\
\text { subjects }\end{array}$ & $\begin{array}{l}\text { BPH group: } \\
63.5 \text { (43-84) } \\
\text { PCa group: } \\
66 \text { (49-84) } \\
\text { Control } \\
\text { group: } 66 \\
(48-78) \\
\end{array}$ & $\begin{array}{l}\text { (i) CuZn-SOD, and GPX } \\
\text { measured by a UV- } \\
\text { VIS recording } \\
\text { spectrophotometer } \\
\text { (ii) MDA }\end{array}$ & $\begin{array}{c}\text { Compared with BPH and control groups, } \\
\text { there is a higher MDA concentration with } \\
\text { lower GPX and CuZn-SOD activities in } \\
\text { PCa patients. }\end{array}$ & {$[46]$} \\
\hline $\begin{array}{l}\text { Srivastava } \\
\text { DS, et al. } \\
2005\end{array}$ & $\begin{array}{l}\text { Case- } \\
\text { control } \\
\text { study }\end{array}$ & $\begin{array}{l}55 \text { patients } \\
\text { with } \mathrm{BPH} \\
45 \text { patients } \\
\text { with } \mathrm{PCa} \\
25 \text { healthy } \\
\text { individuals }\end{array}$ & $\begin{array}{l}\text { BPH group: } \\
59.6 \pm 8.4 \\
\text { PCa group: } \\
61.9 \pm 11.4 \\
\text { Control } \\
\text { group: } 60.5 \\
\pm 14.3\end{array}$ & $\begin{array}{l}\text { (i) GPX measured by kit } \\
\text { (ii) MDA } \\
\text { (iii) GST and GSH } \\
\text { activities measured by } \\
\text { spectrophotometry }\end{array}$ & $\begin{array}{l}\text { Compared with control group, there is a } \\
\text { higher level of MDA concentration and } \\
\text { GST activity and lower levels of GSH } \\
\text { concentration and GPX activity in BPH } \\
\text { and PCa groups. }\end{array}$ & [47] \\
\hline $\begin{array}{l}\text { Aydin A, } \\
\text { et al. } 2006\end{array}$ & $\begin{array}{l}\text { Clinical } \\
\text { study }\end{array}$ & $\begin{array}{l}36 \text { patients } \\
\text { with } \mathrm{BPH} \\
25 \text { patients } \\
\text { with PCa } \\
24 \text { healthy } \\
\text { subjects }\end{array}$ & $\begin{array}{c}\text { BPH group: } \\
64.3 \pm 7.9 \\
\text { PCa group: } \\
67.5 \pm 8.8 \\
\text { Control } \\
\text { group: } 65.0 \\
\pm 6.0\end{array}$ & $\begin{array}{l}\text { (i) The level of TBARS, } \\
\text { SOD, GPX, CAT, Cu, } \\
\text { and } \mathrm{Zn}\end{array}$ & $\begin{array}{l}\text { Compared with control group, the lipid } \\
\text { peroxidation was increased with decreased } \\
\text { SOD activity in BPH and PCa groups. }\end{array}$ & {$[48]$} \\
\hline $\begin{array}{l}\text { Surapaneni } \\
\text { KM, et al. } \\
2006\end{array}$ & $\begin{array}{l}\text { Case- } \\
\text { control } \\
\text { study }\end{array}$ & $\begin{array}{l}30 \text { patients } \\
\text { with PCa } \\
30 \text { healthy } \\
\text { cases }\end{array}$ & NR & $\begin{array}{l}\text { (i) MDA measured by } \\
\text { spectrophotometry } \\
\text { (ii) SOD measured by } \\
\text { Misra and Fridovich } \\
\text { (iii) GST and GSH } \\
\text { activities measured by } \\
\text { spectrophotometry }\end{array}$ & $\begin{array}{l}\text { Compared with control group, there is a } \\
\text { higher level of MDA and SOD and lower } \\
\text { level of GSH in PCa patients. }\end{array}$ & {$[49]$} \\
\hline
\end{tabular}


TABle 2: Continued.

\begin{tabular}{|c|c|c|c|c|c|c|}
\hline Author (year) & $\begin{array}{l}\text { Study } \\
\text { design }\end{array}$ & $\begin{array}{c}\text { Study } \\
\text { population }\end{array}$ & Age (year) & Markers assessed & Main results & Reference \\
\hline $\begin{array}{l}\text { Ozmen } \mathrm{H} \text {, } \\
\text { et al. } 2006\end{array}$ & $\begin{array}{l}\text { Cross- } \\
\text { sectional } \\
\text { study }\end{array}$ & $\begin{array}{l}20 \text { patients } \\
\text { with PCa } \\
21 \text { healthy } \\
\text { cases }\end{array}$ & $\begin{array}{l}\text { PCa group: } \\
72.45 \pm 7.78 \\
\text { Control } \\
\text { group: } 66.33 \\
\pm 8.25\end{array}$ & $\begin{array}{l}\text { (i) MDA and vitamins } \\
\text { measured by HPLC } \\
\text { (ii) SE measured by a } \\
\text { fluorimetric method } \\
\text { (iii) Trace elements and Fe } \\
\text { measured by atomic } \\
\text { absorption } \\
\text { spectrophotometry }\end{array}$ & $\begin{array}{l}\text { The study showed that the administration } \\
\text { of vitamins } \mathrm{A}, \mathrm{C} \text {, and } \mathrm{E} \text { and } \mathrm{SE} \text { and } \mathrm{Zn} \\
\text { may be beneficial in the prevention and } \\
\text { treatment of human prostate cancer. }\end{array}$ & {$[50]$} \\
\hline $\begin{array}{l}\text { Lockett KL, } \\
\text { et al. } 2006\end{array}$ & $\begin{array}{l}\text { Case- } \\
\text { control } \\
\text { study }\end{array}$ & $\begin{array}{l}158 \text { patients } \\
\text { with PCa } \\
128 \text { healthy } \\
\text { cases }\end{array}$ & $\begin{array}{l}\text { PCa group: } \\
65.3 \pm 9.5 \\
\text { Control } \\
\text { group: } 64.4 \\
\pm 9.5\end{array}$ & $\begin{array}{l}\text { (i) DNA damage } \\
\text { evaluated by alkaline } \\
\text { comet assay }\end{array}$ & $\begin{array}{l}\text { The study suggested that DNA damage } \\
\text { may be associated with PCa risk. }\end{array}$ & {$[51]$} \\
\hline $\begin{array}{l}\text { Aryal M, et al. } \\
2007\end{array}$ & $\begin{array}{l}\text { Case- } \\
\text { control } \\
\text { study }\end{array}$ & $\begin{array}{l}48 \text { patients } \\
\text { with } \mathrm{BPH} \\
46 \text { healthy } \\
\text { cases }\end{array}$ & $\begin{array}{l}\text { BPH group: } \\
67 \pm 12 \\
\text { Control } \\
\text { group: } 63.4 \\
\quad \pm 8\end{array}$ & $\begin{array}{l}\text { (i) } \mathrm{MDA} \\
\text { (ii) } \alpha \text {-Tocopherol and } \\
\text { ascorbate }\end{array}$ & $\begin{array}{l}\text { Compared with control group, there is a } \\
\text { higher level of plasma MDA and lower } \\
\text { plasma alpha-Tocopherol and ascorbate } \\
\text { level in patients with BPH. }\end{array}$ & {$[52]$} \\
\hline $\begin{array}{l}\text { Goswami K, } \\
\text { et al. } 2007\end{array}$ & $\begin{array}{l}\text { Case- } \\
\text { control } \\
\text { study }\end{array}$ & $\begin{array}{l}10 \text { patients } \\
\text { with } \mathrm{BPH} \\
10 \text { patients } \\
\text { with } \mathrm{PCa} \\
10 \text { control } \\
\text { subjects }\end{array}$ & $\begin{array}{l}\text { BPH group: } \\
65 \pm 3 \\
\text { PCa group: } \\
67 \pm 4 \\
\text { Control } \\
\text { group: } 65 \pm 7\end{array}$ & $\begin{array}{l}\text { (i) Lipid peroxide was } \\
\text { estimated by } \\
\text { spectrophotometry } \\
\text { (ii) Protein carbonyls } \\
\text { measured by modified } \\
\text { Levine's }\end{array}$ & $\begin{array}{l}\text { Compared with control group, there is a } \\
\text { higher level of lipid peroxides and protein } \\
\text { carbonyls in patients with BPH or PCa, } \\
\text { and PCa patients are more prone to } \\
\text { oxidative damage in compared with BPH } \\
\text { patients. }\end{array}$ & {$[53]$} \\
\hline $\begin{array}{l}\text { Arsova- } \\
\text { Sarafinovska } \\
\text { Z, et al. } 2009^{\text {a }}\end{array}$ & $\begin{array}{l}\text { Case- } \\
\text { control } \\
\text { study }\end{array}$ & $\begin{array}{l}67 \text { patients } \\
\text { with } \mathrm{BPH} \\
73 \text { patients } \\
\text { with } \mathrm{PCa} \\
23 \text { control } \\
\text { subjects }\end{array}$ & $\begin{array}{c}\text { BPH group: } \\
64.3 \pm 7.9 \\
\text { PCa group: } \\
67.5 \pm 8.8 \\
\text { Control } \\
\text { group: } 65.0 \\
\pm 6.0\end{array}$ & $\begin{array}{l}\text { (i) MDA } \\
\text { (ii) CuZn-SOD, GPX, } \\
\text { and CAT measured } \\
\text { by a UV-VIS } \\
\text { recording } \\
\text { spectrophotometer } \\
\text { (iii) } \mathrm{NO}^{-} / \mathrm{NO}^{-} \\
\text {(iv) } 8 \text {-OHdG measured } \\
\text { Highly Sensitive } 8 \text { - } \\
\text { OHdG Check ELISA } \\
\text { Kit }\end{array}$ & $\begin{array}{l}\text { Compared with BPH and control groups, } \\
\text { there is a higher MDA and } \mathrm{NO}^{-} / \mathrm{NO}^{-} \\
\text {concentration with lower GPX and CuZn- } \\
\text { SOD activities in PCa patients. }\end{array}$ & {$[54]$} \\
\hline $\begin{array}{l}\text { Arsova- } \\
\text { Sarafinovska } \\
\text { Z, et al. } 2009^{\mathrm{b}}\end{array}$ & $\begin{array}{l}\text { Case- } \\
\text { control } \\
\text { study }\end{array}$ & $\begin{array}{l}100 \text { patients } \\
\text { with } \mathrm{BPH} \\
34 \text { patients } \\
\text { with } \mathrm{PCa} \\
15 \text { control } \\
\text { subjects }\end{array}$ & $\begin{array}{c}\text { BPH group: } \\
64.3 \pm 7.9 \\
\text { PCa group: } \\
67.5 \pm 8.8 \\
\text { Control } \\
\text { group: } 65.0 \\
\pm 6.0\end{array}$ & $\begin{array}{l}\text { (i) MDA } \\
\text { (ii) CuZn-SOD, GPX, } \\
\text { CAT measured by a } \\
\text { UV-VIS recording } \\
\text { spectrophotometer } \\
\text { (iii) } \mathrm{NO}^{-} / \mathrm{NO}^{-} \\
\text {(iv) } 8-\mathrm{OHdG} \text { measured } \\
\text { Highly Sensitive 8- } \\
\text { OHdG Check ELISA } \\
\text { Kit }\end{array}$ & $\begin{array}{l}\text { Compared with BPH and control groups, } \\
\text { there is a higher MDA and NO2 } 2^{-} / \mathrm{NO}^{-} \\
\text {concentration with lower GPX and CuZn- } \\
\text { SOD activities in PCa patients. }\end{array}$ & {$[54]$} \\
\hline $\begin{array}{l}\text { Pace G, et al. } \\
2010\end{array}$ & $\begin{array}{l}\text { Case- } \\
\text { control } \\
\text { study }\end{array}$ & $\begin{array}{l}7 \text { patients } \\
\text { with } \mathrm{BPH} \\
11 \text { patients } \\
\text { with } \mathrm{PCa} \\
5 \text { healthy } \\
\text { subjects }\end{array}$ & $\begin{array}{c}\text { BPH group: } \\
65.14 \pm 2.12 \\
\text { PCa group: } \\
62.82 \pm 1.74 \\
\text { Control } \\
\text { group: } 66.00 \\
\pm 3.51\end{array}$ & $\begin{array}{l}\text { (i) ox-LDL, peroxides, } \\
\text { TEAC, and SOD } \\
\text { measured in blood } \\
\text { samples }\end{array}$ & $\begin{array}{l}\text { The study confirmed a significant } \\
\text { imbalance of redox status in patients with } \\
\text { BPH and PCa and suggests that oxidative } \\
\text { stress may be a determinant in the } \\
\text { pathogenesis of these diseases. }\end{array}$ & {$[55]$} \\
\hline
\end{tabular}


TABLE 2: Continued.

\begin{tabular}{|c|c|c|c|c|c|c|}
\hline Author (year) & $\begin{array}{l}\text { Study } \\
\text { design }\end{array}$ & $\begin{array}{c}\text { Study } \\
\text { population }\end{array}$ & Age (year) & Markers assessed & Main results & Reference \\
\hline $\begin{array}{l}\text { Hoque A, } \\
\text { et al. } 2010\end{array}$ & $\begin{array}{l}\text { Nested } \\
\text { case- } \\
\text { control } \\
\text { study }\end{array}$ & $\begin{array}{c}1808 \mathrm{PCa} \\
\text { cases } \\
1805 \text { controls }\end{array}$ & $\begin{array}{l}\text { Case group: } \\
63.62 \pm 5.54 \\
\text { Control } \\
\text { group: } 63.58 \\
\pm 5.55\end{array}$ & $\begin{array}{l}\text { (i) Serum protein } \\
\text { carbonyl level } \\
\text { measured by a } \\
\text { noncompetitive ELISA }\end{array}$ & $\begin{array}{c}\text { The study did not support that oxidative } \\
\text { stress plays a role in PCa risk or its } \\
\text { aggressiveness in serum protein carbonyl } \\
\text { level. }\end{array}$ & {$[56]$} \\
\hline $\begin{array}{l}\text { Cimino S, } \\
\text { et al. } 2014\end{array}$ & $\begin{array}{l}\text { Case- } \\
\text { control } \\
\text { study }\end{array}$ & $\begin{array}{l}60 \mathrm{BPH} \\
\text { patients } \\
40 \mathrm{PCa} \\
\text { patients }\end{array}$ & $\begin{array}{l}\text { BPH group: } \\
68 \pm 6.4 \\
\text { PCa group: } \\
67 \pm 8.7\end{array}$ & $\begin{array}{l}\text { (i) The level of total thiol } \\
\text { groups (TTG) and } \\
\text { glutathione }\end{array}$ & $\begin{array}{c}\text { A significant difference of TTG was } \\
\text { observed in BPH and PCa patients, and } \\
\text { the level of glutathione was lower in PCa } \\
\text { patients. }\end{array}$ & {$[57]$} \\
\hline
\end{tabular}

HP: hypertension; CHD: coronary heart disease; $\mathrm{O}_{2}^{-}$: superoxide anion; HIAE: high-intensity aerobic exercise; LIAE: low-intensity aerobic exercise; BFE: blood flow restriction; TBARS: thiobarbituric acid-reactive substances; SOD: the enzyme activities of superoxide dismutase; GPX: glutathione peroxidase; CAT: catalase; Cu: copper; $\mathrm{Zn}$ : zinc; NR: not reported; BPH: benign prostatic hyperplasia; PCa: prostate cancer; TEAC: total equivalent antioxidant capacity; ${ }^{a}$ the data from Macedonia; 'the data from Turkey; MDA: erythrocyte malondialdehyde; $\mathrm{NO}^{-} / \mathrm{NO}^{-}$: nitrite/nitrate; 8 -OHdG: 8 -hydroxy-2 ${ }^{\prime}$-deoxyguanosine; GST: glutathione s-transferase.

hydroxynonenal [HNE]) [36], and DNA oxidation (8hydroxy-2'-deoxyguanosine [8-OHdG]). Although, the biomarkers of measured oxidative stress are indirect and have low specificity, these do provide a noninvasive method in clinical practice.

\section{Pathophysiological Role of Oxidative Stress in CVD and Prostatic Diseases}

Numerous clinical studies have indicated that oxidative stress plays a role in CVD and prostatic diseases (Table 2). Studies have reported that the level of oxidative stress biomarkers was higher in CVD patients [37-40]. Additionally, current evidence suggests that oxidative stress is associated with the etiology and pathogenesis of the prostatic diseases [9, 41-43]. Hence, the phenomenon of CVD increasing the risk of prostatic diseases may be attributed to oxidative stress (Figure 2).

3.1. Renin-Angiotensin System in CVD and Prostatic Diseases. It is well established that the activation of renin-angiotensin system (RAS) is critically associated with the pathogenesis of hypertension and atherosclerosis [58-60]. Previous studies have reported the existence of local RAS in the prostate, and the overactivity of the RAS may be involved in the pathophysiology of BPH and prostate cancer [61-64]. The RAS includes angiotensinogen, renin, angiotensin conversion enzyme (ACE), angiotensin II (Ang II), and angiotensin receptors. Ang II is a biologically active peptide in the RAS, and its main effector receptor is type 1 receptor $\left(\mathrm{AT}_{1} \mathrm{R}\right)$ (Figure 2$)$.

The ACE inhibitors (ACEIs) and angiotensin receptor blockers (ARBs) have been successfully used as antihypertensive medication, and some studies have reported that these drugs have also been used in anticancer therapy $[65,66]$. A meta-analysis which included 9 cohort studies with 20267 patients suggested that the use of ACEIs/ARB may be associated with a decreased risk of prostate cancer [65]. However, another meta-analysis of observational studies did not find a significant relationship between the use of ACEIs/ARB and prostate cancer risk [67]. Although it is still controversial, ACEIs or ARBs have been used to reduce the risk of prostate cancer. One study showed that the expression level of $\mathrm{AT}_{1} \mathrm{R}$ mRNA was higher in prostate cancer than that in the normal human prostate, based on the data, and ACEIs or ARB may inhibit prostate cancer [68]. Another study reported that the ACEI captopril lowers the risk of prostate cancer, but it was not significant [69]. In BPH patients, a clinical study showed that the use of ARB can improve prostatic hyperplasia [70], whereas other antihypertensive drugs were not effective, which indicates that ARB could ameliorate BPH independently of decreasing blood pressure. The ARB drug Losartan could treat the BPH in spontaneously hypertensive rats (SHRs). The study showed that long-term Losartan treatment restored prostatic blood flow and reduced tissue MDA (oxidative stress marker) in SHRs [71]. These findings suggest that ARB/ACEI may also effective in prostatic diseases.

Traditionally, it has been thought that Ang II can directly achieve vasoconstriction by interacting with $\mathrm{AT}_{1} \mathrm{R}$ in vascular smooth muscle. Recently, a novel signalling mechanism for Ang II-induced vascular superoxide $\left(\mathrm{O}_{2}^{-}\right)$formation was associated with the development of endothelial dysfunction, hypertension, and atherosclerosis. The source of this increased $\mathrm{O}_{2}{ }^{-}$seemed to be membrane-bound vascular NADPH oxidases (NOXs) [72, 73]. A study has also reported that angiotensin II also induced the production of ROS prostate cancer cells by upregulating the subunits of NADPH oxidase (NOX) [74]. In addition, another study has found expressions of various NOX isoforms in prostate cancer cell lines and a cross-talk between the endogenous ROS generation by NOX system and the tumorigenic potential [41]. Taken together, the ROS generated by NOX may play the central role connecting CVD and prostatic diseases.

3.2. NOX in CVD and Prostatic Diseases. NOXs are the key enzymes of redox signalling and also the main source of ROS in vivo [75]. ROS are generated by NOX in the pathogenesis of CVD (see Figure 2). In human cells, there are seven isoforms of the NOX family proteins, which are NOX1, NOX2, NOX3, NOX4, NOX5, DUOX1, and DUOX2. NOX1, NOX2, and NOX5 directly generate superoxide anions. Conversely, the NOX4 produces $\mathrm{H}_{2} \mathrm{O}_{2}$ which may be associated with its localization in the mitochondria in 


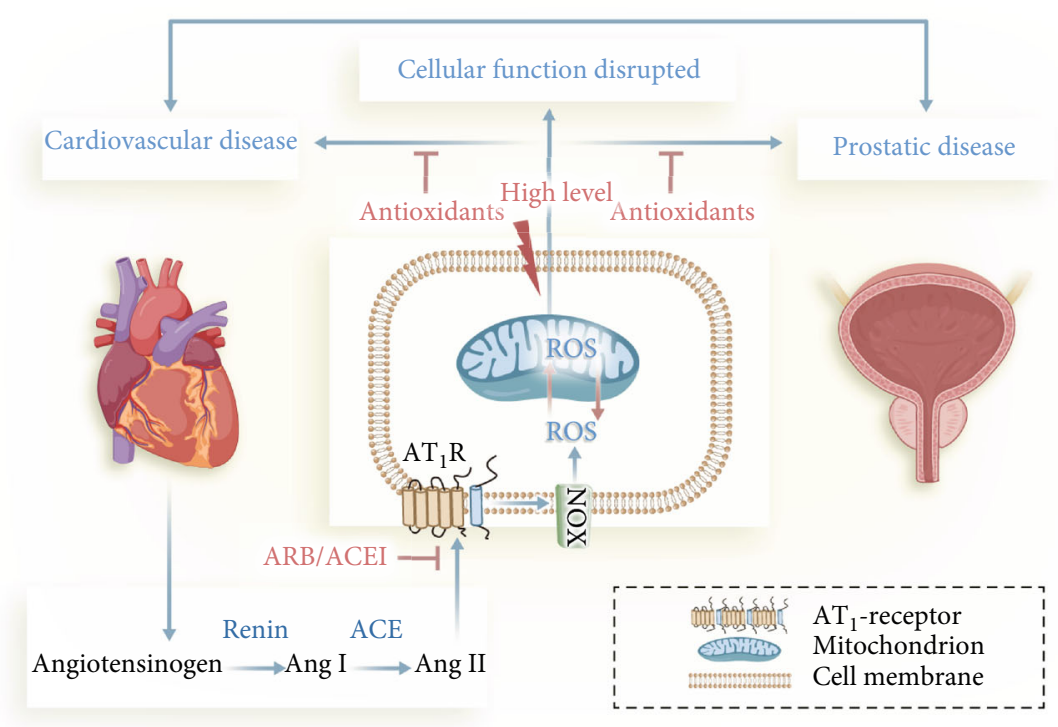

FIgURE 2: ROS generated by NOX in the pathogenesis between CVD and prostatic diseases. The renin-angiotensin system (RAS) exists in both heart and prostate; in addition, the overactivity of the RAS is found in both cardiovascular diseases (CVD) and prostatic diseases. The RAS includes angiotensinogen, renin, angiotensin conversion enzyme (ACE), angiotensin II (Ang II), and angiotensin receptors. Ang II is a biologically active peptide in RAS, and its main effector receptor is the type $1\left(\mathrm{AT}_{1} \mathrm{R}\right)$. Ang II induced the ROS by activation of the subunits of NADPH oxidase (NOX), and then, the increased ROS effects the development of CVD and prostatic diseases. Thus, NOXderived ROS signal may be a common potential target in therapeutic intervention of CVD and prostatic diseases.

cardiomyocytes and in the endoplasmic reticulum in endothelial cells [76-78]. Superoxide cannot cross the membranes of these organelles. DUOX1 and DUOX2 also produce $\mathrm{H}_{2} \mathrm{O}_{2}$ [79]. The transmembrane subunit $\mathrm{P} 22^{\text {phox }}$ and NOX subtypes (NOX1, NOX2, and NOX4) make up the membrane-bound catalytic core [80]. The NOX4 activity requires $\mathrm{P} 22^{\text {phox }}$ and is also regulated by POLDIP2. Of the seven NOXs, NOX1 and NOX2 play a role in immune defence [81], other NOXs act as the second messenger to participate in the regulation of cell signal pathways and maintain the stability of the intracellular environment [82].

3.2.1. NOX and CVD. The association between increased vascular ROS production and hypertension has been reported in animal models with Ang II induced via NOX activation [72]. Some recent in vitro studies have suggested a pivotal role of the NOX and its subunit $\mathrm{p} 47$ phox in vascular oxidant stress and the blood pressure response to angiotensin II [83, 84]. The previous studies have reported that the expression of mRNA in NOX1, NOX2, and NOX4 was increased in aortas from animals infused with Ang II $[85,86]$. In addition, the expression of NOX2, NOX4, and NOX5 was found to be upregulated by Ang II in endothelial cells [87, 88], and knockout of NOX1, NOX2, and NOX4 in mice can reduce blood-pressure elevation induced by Ang II $[86,89,90]$. Taking together, these data suggest that activation of NOX1, NOX2, NOX4, and NOX5 play an important role in the development of Ang II-induced hypertension.

NOX2 is a major ROS source in the heart, and its activity increases after acute myocardial infarction (AMI). Compared with the normal human cardiomyocytes, the expression of
NOX2 was higher in patients with AMI [91]. One study reported that the absence of NOX2 in Apoe-/- mice decreased ROS production, increased NO bioavailability, and reduced aortic atherosclerosis [92]. But Sirker et al. indicated that the overexpression of NOX2 in cardiomyocyte or endothelial cell made no difference to initial infarct size in mice with AMI at 4 weeks [93]. Vendrov et al. [94] suggest that expression of NOX4, but not NOX1 or NOX2, was correlated with increased mitochondrial oxidative stress, mitochondrial and cardiovascular dysfunction, and atherosclerosis in aged mice. The study indicated that NOX4 is a potential therapeutic target for aging-associated cardiovascular disease. The current study also demonstrated that NOX5 expression increased in patients with AMI, especially in infarctions $>12$ hours [95]. In summary, the expression of NOX2, NOX4, and NOX5 plays a role in the development of coronary heart disease.

3.2.2. NOX and Prostatic Diseases. Evidence has showed that the aberrant activation of NOX plays a critical role in prostate cancer growth and progression [96, 97]. A recent study showed that NOX expression is directly associated with prostate cancer in mice, and when NOX was inhibited, the expression of HIF- $1 \alpha$ in the nucleus was significantly decreased as well as a reduction in the proliferation and colony formation of prostate cancer [98]. Some studies have shown that NOX1 and its transmembrane subunit P22 $2^{\text {phox }}$ and NOX5 are overexpressed in prostate cancer [99-102], and downregulated NOX5 expression can inhibit cell proliferation and tumor growth and induce apoptosis of prostate cancer cells [103]. In addition, studies have reported that 
various isoforms of NOX are found in prostate cancer cell lines, including NOX4, NOX2, and NOX5, which are absent in normal prostate cell lines $[104,105]$. An in vitro study has shown that the imbalance of redox homeostasis caused by elevated NOX4-derived ROS signal was the basis of fibroblast-tomyofibroblast differentiation in the diseased prostatic stroma, which indicates NOX4 inhibitors have potential clinical value in the prevention of $\mathrm{BPH}$ and prostate cancer [106]. Thus, NOX1, NOX2, NOX4, and NOX5 may be potential targets for therapeutic intervention in prostate cancer.

\section{Conclusion}

Evidence from clinical and animal studies demonstrates that CVD is associated with prostatic diseases, and oxidative stress may erect a bridge between these diseases; however, the exact mechanism of oxidative stress in CVD and prostatic diseases remains to be further elucidated. We provide a framework for future experimental and clinical studies on the role of known and yet to be discovered oxidative stress in CVD and prostatic diseases. The mechanisms and signalling processes by Ang II increased ROS production via NOX in these diseases is yet to be proved. Furthermore, NOX-derived ROS signals may be a common potential target in therapeutic intervention of CVD and prostatic diseases.

\section{Conflicts of Interest}

The authors declare that there are no conflicts of interests.

\section{References}

[1] G. A. Roth, G. A. Mensah, C. O. Johnson et al., "Global burden of cardiovascular diseases and risk factors, 1990-2019: update from the GBD 2019 study," Journal of the American College of Cardiology, vol. 76, no. 25, pp. 2982-3021, 2020.

[2] GBD 2019 Diseases and Injuries Collaborators, "Global burden of 369 diseases and injuries in 204 countries and territories, 1990-2019: a systematic analysis for the Global Burden of Disease Study 2019," The Lancet, vol. 396, no. 10258, pp. 1204-1222, 2020.

[3] S. J. Berry, D. S. Coffey, P. C. Walsh, and L. L. Ewing, "The development of human benign prostatic hyperplasia with age," The Journal of Urology, vol. 132, no. 3, pp. 474-479, 1984.

[4] T. Deng, L. Cai, Z. Chen, and G. U. Jia, "Analysis of the burden of prostate cancer in China in 1990 and 2017," Yixue Xinzhi Zazhi, vol. 30, no. 4, pp. 252-259, 2020.

[5] Global Burden of Disease Cancer Collaboration, "Global, regional, and national cancer incidence, mortality, years of life lost, years lived with disability, and disability-adjusted life-years for 29 cancer groups, 1990 to 2017: a systematic analysis for the Global Burden of Disease Study," JAMA Oncology, vol. 5, no. 12, pp. 1749-1768, 2019.

[6] X. Liu, C. Yu, Y. Bi, and Z. J. Zhang, "Trends and age-periodcohort effect on incidence and mortality of prostate cancer from 1990 to 2017 in China," Public Health, vol. 172, pp. 70-80, 2019.

[7] C. J. A. Ramachandra, S. Cong, X. Chan, E. P. Yap, F. Yu, and D. J. Hausenloy, "Oxidative stress in cardiac hypertrophy:
From molecular mechanisms to novel therapeutic targets," Free Radical Biology \& Medicine, vol. 166, pp. 297-312, 2021.

[8] T. Münzel, G. G. Camici, C. Maack, N. R. Bonetti, V. Fuster, and J. C. Kovacic, "Impact of Oxidative Stress on the Heart and Vasculature: Part 2 of a 3-Part Series," Journal of the American College of Cardiology, vol. 70, no. 2, pp. 212-229, 2017.

[9] U. K. Udensi and P. B. Tchounwou, "Oxidative stress in prostate hyperplasia and carcinogenesis," Journal of Experimental \& Clinical Cancer Research, vol. 35, no. 1, p. 139, 2016.

[10] G. Gupta-Elera, A. R. Garrett, R. A. Robison, and K. L. O'Neill, "The role of oxidative stress in prostate cancer," European Journal of Cancer Prevention, vol. 21, no. 2, pp. 155-162, 2012.

[11] J. B. Bourke and J. P. Griffin, "Hypertension, diabetes mellitus, and blood groups in benign prostatic hypertrophy," British Journal of Urology, vol. 38, no. 1, pp. 18-23, 1966.

[12] K. Sugaya, K. Kadekawa, A. Ikehara et al., "Influence of hypertension on lower urinary tract symptoms in benign prostatic hyperplasia," International Journal of Urology, vol. 10, no. 11, pp. 569-574, 2003.

[13] M. C. Michel, U. Heemann, H. Schumacher, L. Mehlburger, and M. Goepel, "Association of hypertension with symptoms of benign prostatic hyperplasia," The Journal of Urology, vol. 172, 4, Part 1, pp. 1390-1393, 2004.

[14] I. H. Chen, Y. S. Tsai, and Y. C. Tong, "Correlations among cardiovascular risk factors, prostate blood flow, and prostate volume in patients with clinical benign prostatic hyperplasia," Urology, vol. 79, no. 2, pp. 409-414, 2012.

[15] E. C. Hwang, S. O. Kim, D. H. Nam et al., "Men with hypertension are more likely to have severe lower urinary tract symptoms and large prostate volume," LUTS: Lower Urinary Tract Symptoms, vol. 7, no. 1, pp. 32-36, 2015.

[16] X. T. Zeng, H. Weng, J. Xiong et al., "Comparison of clinical and physiological parameters for benign prostatic hyperplasia in hypertensive and normotensive patients," Frontiers in Physiology, vol. 9, p. 1330, 2018.

[17] S. Navin and V. Ioffe, "The association between hypertension and prostate cancer," Revista de Urología, vol. 19, no. 2, pp. 113-118, 2017.

[18] B. A. Dickerman, J. E. Torfadottir, U. A. Valdimarsdottir et al., "Midlife metabolic factors and prostate cancer risk in later life," International Journal of Cancer, vol. 142, no. 6, pp. 1166-1173, 2018.

[19] K. M. Weisman, G. E. Larijani, M. R. Goldstein, and M. E. Goldberg, "Relationship between benign prostatic hyperplasia and history of coronary artery disease in elderly men," Pharmacotherapy, vol. 20, no. 4, pp. 383-386, 2000.

[20] A. I. Neugut, D. J. Rosenberg, H. Ahsan et al., "Association between coronary heart disease and cancers of the breast, prostate, and colon," Cancer Epidemiology, Biomarkers \& Prevention, vol. 7, no. 10, pp. 869-873, 1998.

[21] K. N. Stamatiou, A. G. Alevizos, K. Mihas, A. D. Mariolis, E. Michalodimitrakis, and F. Sofras, "Associations between coronary heart disease, obesity and histological prostate cancer," International Urology and Nephrology, vol. 39, no. 1, pp. 197-201, 2007.

[22] J. A. Thomas 2nd, L. Gerber, L. L. Bañez et al., "Prostate cancer risk in men with baseline history of coronary artery disease: results from the REDUCE Study," Cancer Epidemiology, Biomarkers \& Prevention, vol. 21, no. 4, pp. 576-581, 2012. 
[23] B. I. Omalu, J. L. Hammers, A. V. Parwani, J. Balani, A. Shakir, and R. B. Ness, "Is there an association between coronary atherosclerosis and carcinoma of the prostate in men aged 50 years and older? An autopsy and coroner based post-mortem study," Nigerian Journal of Clinical Practice, vol. 16, no. 1, pp. 45-48, 2013.

[24] D. Harman, "Aging: a theory based on free radical and radiation chemistry," Journal of Gerontology, vol. 11, no. 3, pp. 298-300, 1956.

[25] R. S. Sohal and R. G. Allen, "Oxidative stress as a causal factor in differentiation and aging: a unifying hypothesis," Experimental Gerontology, vol. 25, no. 6, pp. 499-522, 1990.

[26] H. Sies, "Oxidative stress: oxidants and antioxidants," Experimental Physiology, vol. 82, no. 2, pp. 291-295, 1997.

[27] H. Sies, "Oxidative stress: a concept in redox biology and medicine," Redox Biology, vol. 4, pp. 180-183, 2015.

[28] A. Piwkowska, D. Rogacka, I. Audzeyenka, M. Jankowski, and S. Angielski, "High glucose concentration affects the oxidant-antioxidant balance in cultured mouse podocytes," Journal of Cellular Biochemistry, vol. 112, no. 6, pp. 16611672, 2011.

[29] E. R. Stadtman and R. L. Levine, "Protein oxidation," Annals of the New York Academy of Sciences, vol. 899, pp. 191-208, 2000.

[30] L. J. Marnett, "Oxyradicals and DNA damage," Carcinogenesis, vol. 21, no. 3, pp. 361-370, 2000.

[31] T. M. Paravicini and R. M. Touyz, "NADPH oxidases, reactive oxygen species, and hypertension: clinical implications and therapeutic possibilities," Diabetes Care, vol. 31, no. 2, pp. 170-180, 2008.

[32] K. Jomova and M. Valko, "Advances in metal-induced oxidative stress and human disease," Toxicology, vol. 283, no. 2-3, pp. 65-87, 2011.

[33] L. A. Pham-Huy, H. He, and C. Pham-Huy, "Free radicals, antioxidants in disease and health," International Journal of Biomedical Sciences, vol. 4, no. 2, pp. 89-96, 2008.

[34] A. Phaniendra, D. B. Jestadi, and L. Periyasamy, "Free radicals: properties, sources, targets, and their implication in various diseases," Indian Journal of Clinical Biochemistry, vol. 30, no. 1, pp. 11-26, 2015.

[35] B. D'Autréaux and M. B. Toledano, "ROS as signalling molecules: mechanisms that generate specificity in ROS homeostasis," Nature Reviews Molecular Cell Biology, vol. 8, no. 10, pp. 813-824, 2007.

[36] E. A. Meagher and G. A. FitzGerald, "Indices of lipid peroxidation in vivo: strengths and limitations," Free Radical Biology \& Medicine, vol. 28, no. 12, pp. 17451750, 2000.

[37] G. Germanò, V. Sanguigni, P. Pignatelli et al., "Enhanced platelet release of superoxide anion in systemic hypertension," Journal of Hypertension, vol. 22, no. 6, pp. 11511156, 2004.

[38] M. Guxens, M. Fitó, M. A. Martínez-González et al., "Hypertensive status and lipoprotein oxidation in an elderly population at high cardiovascular risk," American Journal of Hypertension, vol. 22, no. 1, pp. 68-73, 2009.

[39] C. E. Pinzón-Díaz, J. V. Calderón-Salinas, M. M. Rosas-Flores, G. Hernández, A. López-Betancourt, and M. A. QuintanarEscorza, "Eryptosis and oxidative damage in hypertensive and dyslipidemic patients," Molecular and Cellular Biochemistry, vol. 440, no. 1-2, pp. 105-113, 2018.
[40] H. Zhao, Y. Liu, Z. Li et al., "Identification of essential hypertension biomarkers in human urine by non- targeted metabolomics based on UPLC-Q-TOF/MS," Clinica Chimica Acta, vol. 486, pp. 192-198, 2018

[41] B. Kumar, S. Koul, L. Khandrika, R. B. Meacham, and H. K. Koul, "Oxidative stress is inherent in prostate cancer cells and is required for aggressive phenotype," Cancer Research, vol. 68, no. 6, pp. 1777-1785, 2008.

[42] P. L. Minciullo, A. Inferrera, M. Navarra, G. Calapai, C. Magno, and S. Gangemi, "Oxidative stress in benign prostatic hyperplasia: a systematic review," Urologia Internationalis, vol. 94, no. 3, pp. 249-254, 2015.

[43] G. D. Dakubo, R. L. Parr, L. C. Costello, R. B. Franklin, and R. E. Thayer, "Altered metabolism and mitochondrial genome in prostate cancer," Journal of Clinical Pathology, vol. 59, no. 1, pp. 10-16, 2006.

[44] R. A. Merendino, F. Salvo, A. Saija et al., "Malondialdehyde in benign prostate hypertrophy: a useful marker?," Mediators of Inflammation, vol. 12, no. 2, 128 pages, 2003.

[45] K. Camphausen, C. Ménard, M. Sproull, E. Goley, S. Basu, and C. N. Coleman, "Isoprostane levels in the urine of patients with prostate cancer receiving radiotherapy are not elevated," International Journal of Radiation Oncology • Biology • Physics, vol. 58, no. 5, pp. 1536-1539, 2004.

[46] M. I. Yilmaz, K. Saglam, A. Sonmez et al., "Antioxidant system activation in prostate cancer," Biological Trace Element Research, vol. 98, no. 1, pp. 13-20, 2004.

[47] D. S. Srivastava and R. D. Mittal, "Free radical injury and antioxidant status in patients with benign prostate hyperplasia and prostate cancer," Indian Journal of Clinical Biochemistry, vol. 20, no. 2, pp. 162-165, 2005.

[48] A. Aydin, Z. Arsova-Sarafinovska, A. Sayal et al., "Oxidative stress and antioxidant status in non-metastatic prostate cancer and benign prostatic hyperplasia," Clinical Biochemistry, vol. 39, no. 2, pp. 176-179, 2006.

[49] K. M. Surapaneni and G. R. Venkata, "Lipid peroxidation and antioxidant status in patients with carcinoma of prostate," Indian Journal of Physiology and Pharmacology, vol. 50, no. 4, pp. 350-354, 2006.

[50] H. Ozmen, F. A. Erulas, F. Karatas, A. Cukurovali, and O. Yalcin, "Comparison of the concentration of trace metals ( $\mathrm{Ni}, \mathrm{Zn}, \mathrm{Co}, \mathrm{Cu}$ and $\mathrm{Se}$ ), Fe, vitamins $\mathrm{A}, \mathrm{C}$ and $\mathrm{E}$, and lipid peroxidation in patients with prostate cancer," Clinical Chemistry and Laboratory Medicine, vol. 44, no. 2, pp. 175-179, 2006.

[51] K. L. Lockett, M. C. Hall, P. E. Clark et al., "DNA damage levels in prostate cancer cases and controls," Carcinogenesis, vol. 26, no. 6, pp. 1187-1193, 2006.

[52] M. Aryal, A. Pandeya, B. K. Bas et al., "Oxidative stress in patients with benign prostate hyperplasia," JNMA; Journal of the Nepal Medical Association, vol. 46, no. 167, pp. 103106, 2007.

[53] K. Goswami, H. Nandeesha, B. C. Koner, and D. N. Nandakumar, "A comparative study of serum proteinbound sialic acid in benign and malignant prostatic growth: possible role of oxidative stress in sialic acid homeostasis," Prostate Cancer and Prostatic Diseases, vol. 10, no. 4, pp. 356-359, 2007.

[54] Z. Arsova-Sarafinovska, A. Eken, N. Matevska et al., "Increased oxidative/nitrosative stress and decreased antioxidant enzyme activities in prostate cancer," Clinical Biochemistry, vol. 42, no. 12, pp. 1228-1235, 2009. 
[55] G. Pace, C. D. Massimo, D. D. Amicis et al., "Oxidative stress in benign prostatic hyperplasia and prostate cancer," Urologia Internationalis, vol. 85, no. 3, pp. 328-333, 2010.

[56] A. Hoque, C. B. Ambrosone, C. Till et al., "Serum oxidized protein and prostate cancer risk within the Prostate Cancer Prevention Trial," Cancer Prevention Research (Philadelphia, Pa.), vol. 3, no. 4, pp. 478-483, 2010.

[57] S. Cimino, V. Favilla, G. I. Russo et al., "Oxidative stress and body composition in prostate cancer and benign prostatic hyperplasia patients," Anticancer Research, vol. 34, no. 9, pp. 5051-5056, 2014.

[58] G. Nickenig and D. G. Harrison, "The AT(1)-type angiotensin receptor in oxidative stress and atherogenesis: part I: oxidative stress and atherogenesis," Circulation, vol. 105, no. 3, pp. 393-396, 2002.

[59] L. Rothermund and M. Paul, "Hypertension and the renin-angiotensin system-evidence from genetic and transgenic studies," Basic Research in Cardiology, vol. 93, no. 2, 1998.

[60] X. C. Li, J. Zhang, and J. L. Zhuo, “The vasoprotective axes of the renin-angiotensin system: physiological relevance and therapeutic implications in cardiovascular, hypertensive and kidney diseases," Pharmacological Research, vol. 125, Part A, pp. 21-38, 2017.

[61] D. T. Dinh, A. G. Frauman, G. R. Somers et al., "Evidence for activation of the renin-angiotensin system in the human prostate: increased angiotensin II and reduced AT (1) receptor expression in benign prostatic hyperplasia," The Journal of Pathology, vol. 196, no. 2, pp. 213-219, 2002.

[62] L. Nassis, A. G. Frauman, M. Ohishi et al., "Localization of angiotensin-converting enzyme in the human prostate: pathological expression in benign prostatic hyperplasia," The Journal of Pathology, vol. 195, no. 5, pp. 571-579, 2001.

[63] M. E. Fabiani, M. Sourial, W. G. Thomas, C. I. Johnston, C. I. Johnston, and A. G. Frauman, "Angiotensin II enhances noradrenaline release from sympathetic nerves of the rat prostate via a novel angiotensin receptor: implications for the pathophysiology of benign prostatic hyperplasia," The Journal of Endocrinology, vol. 171, no. 1, pp. 97-108, 2001.

[64] K. Domińska, K. Kowalska, K. A. Urbanek, D. E. HabrowskaGórczyńska, T. Ochędalski, and A. W. Piastowska Ciesielska, "The impact of Ang-(1-9) and Ang-(3-7) on the biological properties of prostate cancer cells by modulation of inflammatory and steroidogenesis pathway genes," International Journal of Molecular Sciences, vol. 21, no. 17, p. 6227, 2020.

[65] Y. Q. Mao, X. Xu, X. Wang, X. Y. Zheng, and L. P. Xie, "Is angiotensin-converting enzyme inhibitors/angiotensin receptor blockers therapy protective against prostate cancer?," Oncotarget, vol. 7, no. 6, pp. 6765-6773, 2016.

[66] H. Lindberg, D. Nielsen, B. V. Jensen, J. Eriksen, and T. Skovsgaard, "Angiotensin converting enzyme inhibitors for cancer treatment?," Acta Oncologica, vol. 43, no. 2, pp. 142-152, 2004.

[67] L. Cao, S. Zhang, C. M. Jia et al., “Antihypertensive drugs use and the risk of prostate cancer: a meta-analysis of 21 observational studies," BMC Urology, vol. 18, no. 1, p. 17, 2018.

[68] H. Uemura, H. Ishiguro, N. Nakaigawa et al., "Angiotensin II receptor blocker shows antiproliferative activity in prostate cancer cells: a possibility of tyrosine kinase inhibitor of growth factor," Molecular Cancer Therapeutics, vol. 2, no. 11, pp. 1139-1147, 2003.
[69] G. Ronquist, L. A. Rodríguez, A. Ruigómez et al., "Association between captopril, other antihypertensive drugs and risk of prostate cancer," Prostate, vol. 58, no. 1, pp. 50-56, 2004.

[70] H. Ito, M. Taga, K. Tsuchiyama, H. Akino, and O. Yokoyama, "IPSS is lower in hypertensive patients treated with angiotensin-II receptor blocker: posthoc analyses of a lower urinary tract symptoms population," Neurourology and Urodynamics, vol. 32, no. 1, pp. 70-74, 2013.

[71] S. Shimizu, Y. Nagao, T. Shimizu, Y. Higashi, T. Karashima, and M. Saito, "Therapeutic effects of losartan on prostatic hyperplasia in spontaneously hypertensive rats," Life Sciences, vol. 266, article 118924, 2021.

[72] S. Rajagopalan, S. Kurz, T. Münzel et al., "Angiotensin IImediated hypertension in the rat increases vascular superoxide production via membrane NADH/NADPH oxidase activation. Contribution to alterations of vasomotor tone," The Journal of Clinical Investigation, vol. 97, no. 8, pp. 1916-1923, 1996.

[73] U. Rueckschloss, M. T. Quinn, J. Holtz, and H. Morawietz, "Dose-dependent regulation of $\mathrm{NAD}(\mathrm{P}) \mathrm{H}$ oxidase expression by angiotensin II in human endothelial Cells," Arteriosclerosis, Thrombosis, and Vascular Biology, vol. 22, no. 11, pp. 1845-1851, 2002.

[74] H. Uemura, H. Ishiguro, Y. Ishiguro, K. Hoshino, S. Takahashi, and Y. Kubota, "Angiotensin II induces oxidative stress in prostate cancer," Molecular Cancer Research, vol. 6, no. 2, pp. 250-258, 2008.

[75] N. Y. Spencer and J. F. Engelhardt, "The basic biology of redoxosomes in cytokine-mediated signal transduction and implications for disease-specific therapies," Biochemistry, vol. 53, no. 10, pp. 1551-1564, 2014.

[76] S. Dikalov, A. Dikalova, A. Bikineyeva, H. Schmidt, D. Harrison, and K. Griendling, "Distinct roles of Nox1 and Nox4 in basal and angiotensin II-stimulated superoxide and hydrogen peroxide production," Free Radical Biology \& Medicine, vol. 45, no. 9, pp. 1340-1351, 2008.

[77] I. Helmcke, S. Heumüller, R. Tikkanen, K. Schröder, and R. P. Brandes, "Identification of structural elements in Noxl and Nox4 controlling localization and activity," Antioxidants \& Redox Signaling, vol. 11, no. 6, pp. 1279-1287, 2009.

[78] K. Block, Y. Gorin, and H. E. Abboud, "Subcellular localization of Nox4 and regulation in diabetes," Proceedings of the National Academy of Sciences of the United States of America, vol. 106, no. 34, pp. 14385-14390, 2009.

[79] J. D. Lambeth, T. Kawahara, and B. Diebold, "Regulation of Nox and Duox enzymatic activity and expression," Free Radical Biology \& Medicine, vol. 43, no. 3, pp. 319-331, 2007.

[80] R. P. Brandes, N. Weissmann, and K. Schröder, "Nox family NADPH oxidases: molecular mechanisms of activation," Free Radical Biology \& Medicine, vol. 76, pp. 208-226, 2014.

[81] M. Torres, "Mitogen-activated protein kinase pathways in redox signalling," Frontiers in Bioscience, vol. 8, pp. 369391, 2003.

[82] S. Mao and S. Huang, "The signaling pathway of NADPH oxidase and its role in glomerular diseases," Journal of Receptor and Signal Transduction Research, vol. 34, no. 1, pp. 6-11, 2014.

[83] M. C. Lavigne, H. L. Malech, S. M. Holland, and T. L. Leto, "Genetic demonstration of p47phox-dependent superoxide anion production in murine vascular smooth muscle cells," Circulation, vol. 104, no. 1, pp. 79-84, 2001. 
[84] U. Landmesser, H. Cai, S. Dikalov et al., "Role of p47(phox) in vascular oxidative stress and hypertension caused by angiotensin II," Hypertension, vol. 40, no. 4, pp. 511-515, 2002.

[85] M. Higashi, H. Shimokawa, T. Hattori et al., "Long-term inhibition of Rho-kinase suppresses angiotensin II-induced cardiovascular hypertrophy in rats in vivo: effect on endothelial NAD(P)H oxidase system," Circulation Research, vol. 93, no. 8, pp. 767-775, 2003.

[86] K. Matsuno, H. Yamada, K. Iwata et al., "Nox1 is involved in angiotensin II-mediated hypertension: a study in Nox1deficient mice," Circulation, vol. 112, no. 17, pp. 2677-2685, 2005.

[87] G. Z. Liang, L. M. Cheng, X. F. Chen et al., "ClC-3 promotes angiotensin II-induced reactive oxygen species production in endothelial cells by facilitating Nox2 NADPH oxidase complex formation," Acta Pharmacologica Sinica, vol. 39, no. 11, pp. 1725-1734, 2018.

[88] A. C. Montezano, D. Burger, T. M. Paravicini et al., "Nicotinamide adenine dinucleotide phosphate reduced oxidase 5 (Nox5) regulation by angiotensin II and endothelin-1 is mediated via calcium/calmodulin-dependent, rac-1independent pathways in human endothelial cells," Circulation Research, vol. 106, no. 8, pp. 1363-1373, 2010.

[89] H. D. Wang, S. Xu, D. G. Johns et al., "Role of NADPH oxidase in the vascular hypertrophic and oxidative stress response to angiotensin II in mice," Circulation Research, vol. 88, no. 9, pp. 947-953, 2001.

[90] G. Bouabout, E. Ayme-Dietrich, H. Jacob et al., "Effets de l'inhibition constitutive de la Nox4 dans l'hypertension arterielle experimentale et le syndrome metabolique," Archives of Cardiovascular Diseases, vol. 111, no. 1, pp. 41-52, 2018.

[91] P. A. Krijnen, C. Meischl, C. E. Hack et al., "Increased Nox2 expression in human cardiomyocytes after acute myocardial infarction," Journal of Clinical Pathology, vol. 56, no. 3, pp. 194-199, 2003.

[92] C. P. Judkins, H. Diep, B. R. S. Broughton et al., "Direct evidence of a role for Nox2 in superoxide production, reduced nitric oxide bioavailability, and early atherosclerotic plaque formation in ApoE-/- mice," American Journal of Physiology. Heart and Circulatory Physiology, vol. 298, no. 1, pp. 24-32, 2010.

[93] A. Sirker, C. E. Murdoch, A. Protti et al., "Cell-specific effects of Nox2 on the acute and chronic response to myocardial infarction," Journal of Molecular and Cellular Cardiology, vol. 98, pp. 11-17, 2016.

[94] A. E. Vendrov, K. C. Vendrov, A. Smith et al., "NOX4 NADPH oxidase-dependent mitochondrial oxidative stress in aging-associated cardiovascular disease," Antioxidants \& Redox Signaling, vol. 23, no. 18, pp. 1389-1409, 2015.

[95] N. E. Hahn, C. Meischl, T. Kawahara et al., "NOX5 expression is increased in intramyocardial blood vessels and cardiomyocytes after acute myocardial infarction in humans," The American Journal of Pathology, vol. 180, no. 6, pp. 22222229, 2012.

[96] K. Roy, Y. Wu, J. L. Meitzler et al., "NADPH oxidases and cancer," Clinical Science (London, England), vol. 128, no. 12, pp. 863-875, 2015.

[97] K. Block and Y. Gorin, "Aiding and abetting roles of NOX oxidases in cellular transformation," Nature Reviews. Cancer, vol. 12, no. 9, pp. 627-637, 2012.
[98] G. Deep, R. Kumar, A. K. Jain et al., "Graviola inhibits hypoxia-induced NADPH oxidase activity in prostate cancer cells reducing their proliferation and clonogenicity," Scientific Reports, vol. 6, no. 1, article 23135, 2016.

[99] S. D. Lim, C. Sun, J. D. Lambeth et al., "Increased Nox1 and hydrogen peroxide in prostate cancer," Prostate, vol. 62, no. 2, pp. 200-207, 2005.

[100] M. Höll, R. Koziel, G. Schäfer et al., "ROS signaling by NADPH oxidase 5 modulates the proliferation and survival of prostate carcinoma cells," Molecular Carcinogenesis, vol. 55 , no. 1 , pp. 27-39, 2016.

[101] V. Laurent, A. Toulet, C. Attané et al., "Periprostatic adipose tissue favors prostate cancer cell invasion in an obesitydependent manner: role of oxidative stress," Molecular Cancer Research, vol. 17, no. 3, pp. 821-835, 2019.

[102] Q. Li, G. B. Fu, J. T. Zheng et al., "NADPH oxidase subunit p $22^{\text {phox }}$-mediated reactive oxygen species contribute to angiogenesis and tumor growth through AKT and ERK1/2 signaling pathways in prostate cancer," Biochimica et Biophysica Acta (BBA) - Molecular Cell Research, vol. 1833, no. 12, pp. 3375-3385, 2013.

[103] S. S. Brar, Z. Corbin, T. P. Kennedy et al., "NOX5 NAD(P)H oxidase regulates growth and apoptosis in DU 145 prostate cancer cells," American Journal of Physiology. Cell Physiology, vol. 285, no. 2, pp. 353-369, 2003.

[104] L. Khandrika, B. Kumar, S. Koul, H. K. Koul, and H. K. Koul, "Oxidative stress in prostate cancer," Cancer Letters, vol. 282, no. 2, pp. 125-136, 2009.

[105] Y. Miyata, T. Matsuo, Y. Sagara, K. Ohba, K. Ohyama, and H. Sakai, "A mini-review of reactive oxygen species in urological cancer: correlation with NADPH oxidases, angiogenesis, and apoptosis," International Journal of Molecular Sciences, vol. 18, no. 10, article 2214, 2017.

[106] N. Sampson, R. Koziel, C. Zenzmaier et al., "ROS Signaling by NOX4 drives fibroblast-to-myofibroblast differentiation in the diseased prostatic stroma," Molecular Endocrinology, vol. 25, no. 3, pp. 503-515, 2011. 